University of Nebraska - Lincoln

DigitalCommons@University of Nebraska - Lincoln

Faculty Publications from the Harold W. Manter Laboratory of Parasitology

1999

\title{
Eimeria from Bats of Bolivia: Two New Species from Vespertilionid Bats
}

Donald W. Duszynski

University of New Mexico, eimeria@unm.edu

Damien T. Scott

University of New Mexico

Xiaomin Zhao

University of New Mexico

Follow this and additional works at: https://digitalcommons.unl.edu/parasitologyfacpubs

Part of the Parasitology Commons

Duszynski, Donald W.; Scott, Damien T.; and Zhao, Xiaomin, "Eimeria from Bats of Bolivia: Two New Species from Vespertilionid Bats" (1999). Faculty Publications from the Harold W. Manter Laboratory of Parasitology. 153.

https://digitalcommons.unl.edu/parasitologyfacpubs/153

This Article is brought to you for free and open access by the Parasitology, Harold W. Manter Laboratory of at DigitalCommons@University of Nebraska - Lincoln. It has been accepted for inclusion in Faculty Publications from the Harold W. Manter Laboratory of Parasitology by an authorized administrator of DigitalCommons@University of Nebraska - Lincoln. 


\title{
EIMERIA FROM BATS OF BOLIVIA: TWO NEW SPECIES FROM VESPERTILIONID BATS
}

\author{
Donald W. Duszynski, Damien T. Scott, and Xiaomin Zhao
}

Department of Biology, The University of New Mexico, Albuquerque, New Mexico 87131

\begin{abstract}
Between 1985 and 1987, fecal samples were collected from 71 bats representing 14 species (Desmodontidae, Molossidae, Noctilionidae, Phyllostomidae, Vespertilionidae) from 8 localities in 3 states (Beni, Pando, Santa Cruz) in Bolivia, South America. Of these, 2 black myotid bats (Vespertilionidae), Myotis nigricans, and 1 tent-making bat (Phyllostomidae), Uroderma magnirostrum, had oocysts in their feces that represent undescribed species of Eimeria. The new species from M. nigricans (2/ $4,50 \%)$ has sporulated oocysts that are subspheroidal, $18.9 \times 16.9(17-23 \times 14-20) \mu \mathrm{m}$, without a micropyle; oocyst residuum of 6-8 spheroidal globules and 1 highly refractile polar granule are present. The oocyst wall has 2 layers $(\sim 1.3 \mu \mathrm{m}$ thick), with a rough outer layer. Ovoidal sporocysts are $10.1 \times 7.4(7-14 \times 5-10) \mu \mathrm{m}$, with a Stieda body, substieda body, and a sporocyst residuum. The new eimerian species from $U$. magnirostrum $(1 / 2,50 \%)$ has sporulated oocysts that are subspheroidal to ellipsoidal, $23.8 \times 20.8(20-26 \times 19-24) \mu \mathrm{m}$, without micropyle or oocyst residuum, but 1-3 polar granules are present. The oocyst wall has 2 layers $(\sim 1.5 \mu \mathrm{m}$ thick), with a rough, mammilated outer layer. Ovoidal sporocysts are $11.6 \times 8.6(10-12 \times 7-10) \mu \mathrm{m}$, with a Stieda body, substieda body and a sporocyst residuum.
\end{abstract}

The occurrence of eimerian infections in bats may be lower than their occurrence in other mammalian orders. In their review of the Eimeria spp. from bats, Scott and Duszynski (1997) listed only 17 valid species and an average prevalence of $<10 \%$ in all surveys conducted to date. However, as more bat species are examined for coccidia, it is possible that the paucity of Eimeria species found in bats actually may be due to a previous lack of searching for them. In this paper, we describe 2 new

Received 23 July 1998; revised 16 November 1998; accepted 16 November 1998 . eimerian species from Bolivian bats and discuss some of the factors that may influence the prevalence of eimerian infections in this host order (Chiroptera).

\section{MATERIALS AND METHODS}

The hosts were collected with mist nets from 1985 to 1987 as part of a long-term survey of Bolivian mammals. Feces were taken directly from the intestines of all the bats that were collected as voucher specimens, which are deposited in the Museum of Southwestern Biology (MSB), the University of New Mexico (UNM). General procedures for preserving fecal material and measuring and photographing oocysts were described earlier (Duszynski and Wilber, 1997); however, because

TABLE I. Bats collected from 8 localities in 3 states in Bolivia, South America, and examined for Coccidia.

\begin{tabular}{|c|c|c|}
\hline \multicolumn{3}{|l|}{ Desmodontidae } \\
\hline Desmodus rotundus & Beni: Estacion Biologia del Beni & $0 / 2$ \\
\hline \multicolumn{3}{|l|}{ Molossidae } \\
\hline Molossus ater & Santa Cruz: Caranda & $0 / 1$ \\
\hline \multicolumn{3}{|l|}{ Noctilionidae } \\
\hline \multirow[t]{2}{*}{ Noctilio albiventris } & Pando: Independencia & $0 / 1$ \\
\hline & Beni: Rio Tijamuchi & $0 / 1$ \\
\hline \multicolumn{3}{|l|}{ Phyllostomidae } \\
\hline Chiroderma villosum & Pando: Independencia & $0 / 2$ \\
\hline Phyllostomus hastatus & Beni: Rio Matos & $0 / 2$ \\
\hline \multirow[t]{2}{*}{ Uroderma magnirostrum } & Santa Cruz: San Ramon & $1 / 1$ \\
\hline & Santa Cruz: Zoo & $0 / 1$ \\
\hline Vampyrops liaeatus & Santa Cruz: Zoo & $0 / 2$ \\
\hline Vampyrum spectrum & Beni: Rio Tijamuchi & $0 / 2$ \\
\hline \multicolumn{3}{|l|}{ Vespertilionidae } \\
\hline Lasiurus intermedius & Santa Cruz: Caranda & $0 / 1$ \\
\hline \multirow{2}{*}{ Myotis nigricans } & Santa Cruz: Buena Vista & $2 / 3(67)$ \\
\hline & Santa Cruz: Zoo & $0 / 1$ \\
\hline 5 Families, 14 species & 3 States, 8 localities & $3 / 71(4)$ \\
\hline
\end{tabular}



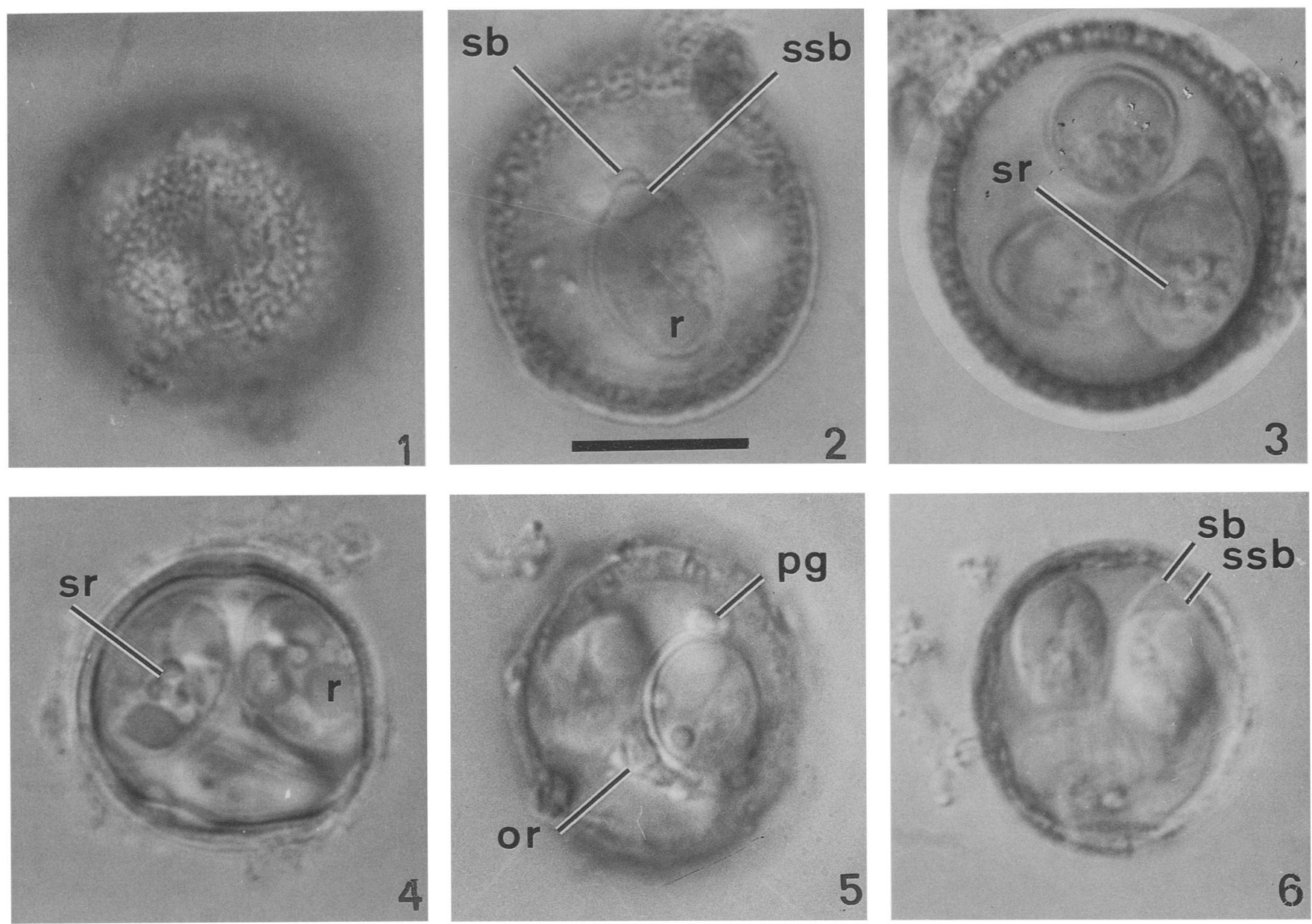

FIGURES 1-6. Photomicrographs of sporulated oocysts of Eimeria magnirostrumi from Uroderma magnirostrum (1-3) and of Eimeria nigricani from Myotis nigricans (4-6), both from Santa Cruz, Bolivia, South America. Scale bar $=10 \mu \mathrm{m}$. 1. Note distinct mammilated outer surface. 2. Note Stieda and substieda bodies. 3. Note striated appearance of oocyst wall(s) in optical cross section and sporocyst residuum. 4. Note sporocyst residuum and refractile body in sporozoite. 5. Note oocyst residuum and refractile polar granule. 6. Note Stieda and substieda bodies and oocyst wall, which is thinner than that of E. magnirostrumi and does not give striated appearance in optical cross section. Abbreviations: pg, polar granule; r, refractile body of sporozoite; sb, Stieda body; ssb, substieda body; sr, sporocyst residuum.

the oocysts were collected and measured prior to that publication, not all recommendations outlined by Duszynski and Wilber (1997) could be met. Oocysts were 235-500 days old when measured. All measurements are in $\mu \mathrm{m}$ with the mean in parentheses following the size ranges. Photosyntypes (see Bandoni and Duszynski, 1988; Duszynski et al., 1999) of sporulated oocysts were deposited into the U.S. National Parasite Collection (USNPC), Beltsville, Maryland. Symbiotype hosts (Frey et al., 1992) are maintained in the Division of Mammals, MSB, UNM.

\section{RESULTS}

Of the 71 bats examined for coccidia, $3(4 \%)$ had eimerian oocysts in their feces, including 2 of 4 Myotis nigricans (Vespertilionidae) and 1 of 2 Uroderma magnirostrum (Phyllostomidae) (Table I).

\section{Eimeria magnirostrumi n. sp. \\ (Figs. 1-3, 7)}

Diagnosis: Oocyst wall $\sim 1.5$ thick, consisting of 2 layers: outer, yellowish-brown, uniformly mammilated, $\sim 2 / 3$ of total thickness, gives a striated appearance in optical cross section; inner, smooth; oocyst residuum and micropyle absent, but $1-3$ polar granules present $(\sim 2.3$ in diameter); sporulated oocysts $(n=56)$ subspheroidal, $20-26 \times 19$
$24(23.8 \times 20.8)$, with $\mathrm{L}: \mathrm{W}$ ratio $1.0-1.4(1.1)$; sporocysts $(\mathrm{n}=56)$ ovoidal, $10-12 \times 7-10(11.6 \times 8.6)$, with L:W ratio $1.1-1.8(1.4)$; Stieda body $(\sim 1.3$ wide) and substieda body $(\sim 2.6$ wide) prominent, but parastieda body absent. Sporocyst residuum dispersed in center of sporocysts, composed of spheroid globules; sporozoites with 1 large, posterior refractile body.

\section{Taxonomic summary}

Symbiotype host: Uroderma magnirostrum (Davis, 1968).

Type locality: Bolivia, Santa Cruz, $10 \mathrm{~km}$ north of San Ramon, $16^{\circ} 36^{\prime} \mathrm{S}, 62^{\circ} 42^{\prime} \mathrm{W}$.

Prevalence: One of $2(50 \%)$.

Site of infection: Unknown, oocysts collected from feces.

Material deposited: Photosyntypes in the USNPC, no. 88104. Symbiotype, U. magnirostrum, MSB 55908 (NK 12988, 8 August 1985).

Etymology: The nomen triviale is derived from the specific epithet of the host name, in the genitive singular ending, meaning "of magnirostrum."

\section{Remarks}

Eimeria magnirostrumi is most similar to Eimeria macyi Wheat, 1975 from Pipistrellus sublavus from Alabama, USA (Wheat, 1975) in that they both have a rough outer wall, have Stieda and substieda bodies, and lack an oocyst residuum. They differ because E. magnirostrumi (1) 


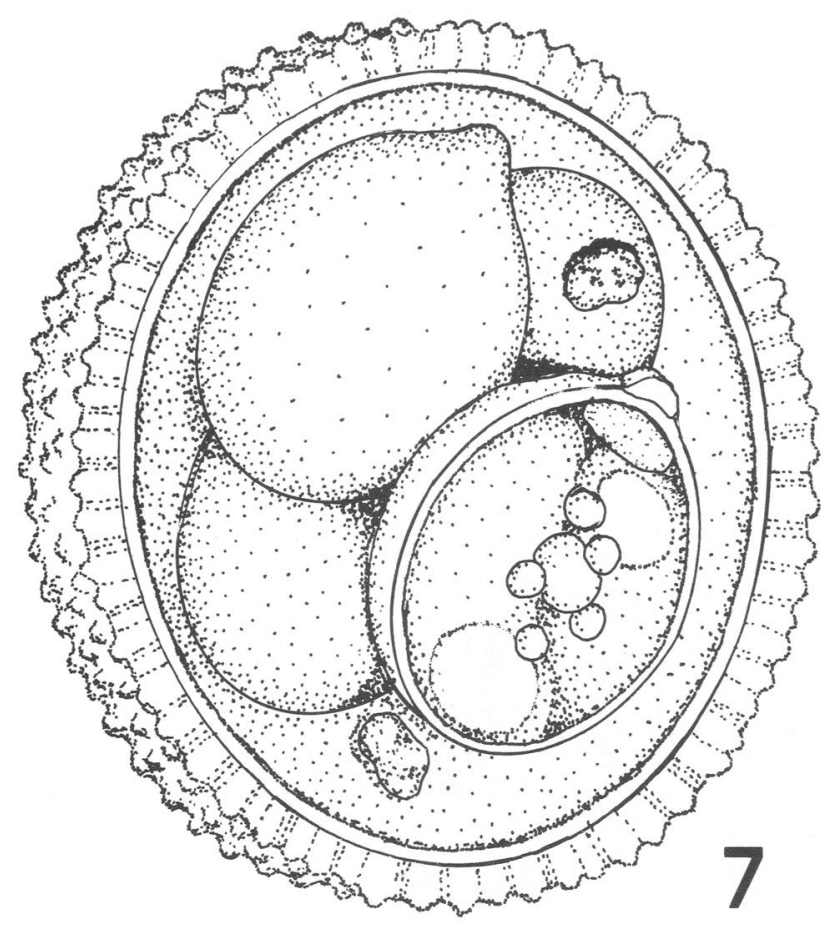

sporocysts $(\mathrm{n}=91)$ ovoidal, $7-14 \times 5-10(10.1 \times 7.4)$, with L:W ratio 1.0-2.1 (1.4); Stieda body $(\sim 1.5)$ and a faint substieda body $(\sim 3$ wide, flat on the bottom) present, but parastieda body absent. Sporocyst residuum a mass of 3-4 round globules $(\sim 1.0$ in diameter); sporozoites with 1 or 2 prominent refractile bodies.

\section{Taxonomic summary}

Symbiotype host: Myotis nigricans (Schinz, 1821).

Type locality: Bolivia, Santa Cruz, $4.0 \mathrm{~km}$ south of Buena Vista, $17^{\circ} 28^{\prime} \mathrm{S}, 63^{\circ} 42^{\prime} \mathrm{W}$

Prevalence: Two of $4(50 \%)$.

Site of infection: Unknown. Oocysts collected from feces.

Material deposited: Photosyntypes in the USNPC, no. 88105. Symbiotype, M. nigricans, MSB 58759 (NK 15201, 2 August 1987).

Etymology: The nomen triviale is derived from the specific epithet of the host name, in the genitive singular ending, meaning "of nigricans."

\section{Remarks}

The presence of a rough outer wall and Stieda and substieda bodies make sporulated oocysts of E. nigricani similar to those of E. magnirostrumi and E. macyi. However, those of E. nigricani differ from $E$. magnirostrumi by having smaller oocysts $(19 \times 17$ vs. $24 \times 21)$ with a rough but not distinctly mammilated outer wall, by having an oocyst residuum of dispersed globules, by having sporozoites with 2 refractile bodies (vs. 1), and a substieda body that is somewhat larger (3.0 vs. 2.6) and flat, rather than rounded, at the bottom. They differ from those of E. macyi in more subtle ways: by the presence of a 2-layered outer wall (vs. 1), the presence of an oocyst residuum, and by having a substieda body that is $2 \times$ wider than the Stieda body (vs. 1 that is not wider than the Stieda body and rounded on the bottom).

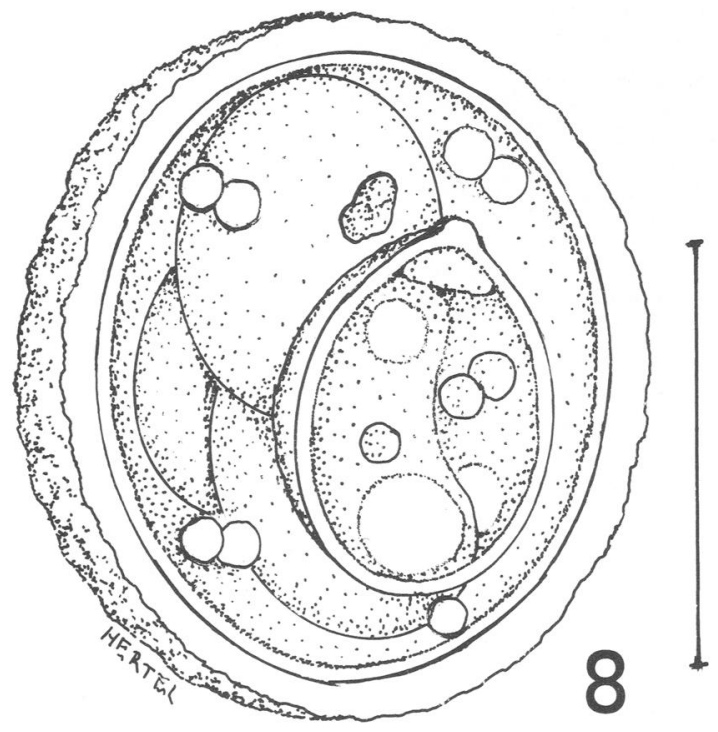

\section{DISCUSSION}

As more bat Eimeria spp. are found and described, we should be able to make more reasonable predictions concerning the factors that contribute to the prevalence of Eimeria spp. in bats. Scott and Duszynski (1997) suggested that colonial bats that roost in stable microclimates may be more likely to be infected with Eimeria spp. Female tent-building bats, like $U$. magnirostrum, will roost in groups of 20-40 individuals; however, males roost either singly or in smaller groups than the females (Nowak, 1994). Thus, females should be more likely to be infected by parasites with direct life cycles like the coccidia. The tentmaking bat that was infected in this study was a female, but our sample size $(\mathrm{n}=2)$ is too small to support any prediction. If colonial bats actually have a greater prevalence of Eimeria spp., then we might expect free-tailed bats (Molossidae) such as Tadarida and Molossus spp., which form large colonies, to be more heavily infected then noncolonial forms. However, Scott and Duszynski (1997) found no Eimeria spp. in $20 \mathrm{Mex}-$ ican free-tailed bats ( $T$. brasiliensis) they examined, nor did we find any in the 39 Molossus spp. caught in this study, both sexes of which were roosting together when captured.

In this paper, we described 2 new eimerian species with sporhas a thicker wall than $E$. macyi (1.5 vs. 1), (2) has 2 wall layers (vs. 1), (3) is somewhat larger than E. macyi $(24 \times 21$ vs. $19 \times 18)$, and (4) has a substieda body that is $2 \times$ wider than its Stieda body, whereas both structures in E. macyi are of equal width (fig. 1 in Wheat, 1975).

\section{Eimeria nigricani n. sp.}

(Figs. 4-6, 8)

Diagnosis: Oocyst wall 1.0-1.4 ( 1.3) thick, consisting of 2 layers: outer, brownish, rough, $\sim 2 / 3$ of total thickness, but does not appear striated in optical cross section; inner, smooth; micropyle absent; oocyst residuum of 6-8 spheroidal globules dispersed throughout oocyst and 1 highly refractile polar granule present; sporulated oocysts $(n=91)$ spheroidal, $17-23 \times 14-20(18.9 \times 16.9)$, with L:W ratio $1.0-1.3(1.1)$; ulated oocysts that are morphologically similar to each other, to those of E. macyi, and to those of 4 other described Eimeria spp. from bats (Eimeria eumops, Eimeria tadarida, Eimeria tomopea, Eimeria redukeri; see Scott and Duszynski [1997] for review). Thus, 7 of the 19 (37\%) eimerian species described to date from bats from around the world share these structural features: spheroidal-subspheroidal shape; thick, highly sculptured outer wall without a micropyle, 1-3 polar granules, ovoidal sporocysts with Stidea body and a sporocyst residuum. This strong structural similarity may suggest that the eimerian par- 
asites in bats are highly conserved, that these species may share an ancient ancestry, or that this particular structural arrangement may provide some selective advantage to the species that possess it, or both.

Light microscopy and photomicroscopy are the most common tools that the practitioner uses for observing species difference between or among sporulated oocysts of coccidia. Given the structural similarity exhibited by many of the sporulated oocysts of bats, as noted here, molecular techniques or transmission electron microscopy eventually may be required to distinguish definitively between some of these morphologically similar Eimeria spp. However, because light microscopy is still the most practical and efficient way to observe and describe eimerian species, the guidelines set forth by Duszynski and Wilber (1997) should be followed, whenever possible, to make it easier for others to compare species information.

\section{ACKNOWLEDGMENTS}

We are grateful to the many mammalogy and parasitology students and faculty, who worked long hours in the field to collect hosts and save their feces for our work, to J. A. Hnida for reviewing earlier drafts of the manuscript, and to Lynn Her- tel for the line drawings. We also thank P. Stidstone who screened the fecal samples and measured the oocysts. This work was supported, in part, by NSF BSR-8408923 to T. L. Yates and a PEET grant, DEB-9521687, to D.W.D.

\section{LITERATURE CITED}

BANDONI, S., AND D. W. DuszYnSKI. 1988. A plea for improved presentation of type material for coccidia. Journal of Parasitology 74: 519-523.

Duszynski, D. W., D. T. Scott, J. Aragon, A. Leach, and T. Perry. 1999. Six new Eimeria species from vespertilionid bats of North America. Journal of Parasitology 85: 496-503.

, AND P. G. WILBER. 1997. A guideline for the preparation of species descriptions in the Eimeriidae. Journal of Parasitology 83 333-336.

Frey, J. K., T. L. Yates, D. W. Duszynski, W. L. Gannon, and S. L. GARDNER. 1992. Designation and curatorial management of type host specimens (symbiotypes) for new parasite species. Journal of Parasitology 78: 930-932.

NowaK, R. M. 1994. Walker's bats of the world. The John Hopkins Press, Ltd., London, U.K., 287 p.

ScotT, D. T., AND D. W. DuszynskI. 1997. Eimeria from bats of the world: two new species from Myotis spp. (Chiroptera: Vespertilionidae). Journal of Parasitology 83: 495-501.

WheAt, B. E. 1975. Eimeria macyi sp. n. (Protozoa: Eimeriidae) from the Eastern pipistrelle, Pipistrellus subflavus, from Alabama. Journal of Parasitology 61: 920-922. 